\title{
In vitro maturation with letrozole priming: Can it be a solution for patients with cancerophobia? A pilot study
}

\section{Letrozol ile öncüllenmis in vitro maturasyon: Kanserfobik hastalarda bir çözüm olabilir mi? Bir pilot çalışma}

\author{
(1) Şafak Hatırnaz ${ }^{1}$, (1) Ebru Saynur Hatırnaz ${ }^{1}$, (1) Alper Başbuğ $\breve{g}^{3}$, (1) Mine Kanat Pektaş ${ }^{4}$, (1) Onur Erol $^{5}$, \\ (1) Michael Dahan ${ }^{2}$, $\odot$ Seang $\operatorname{Tan}^{6}$ \\ ${ }_{1}^{1}$ Medicana Samsun International Hospital, Samsun, Turkey \\ ${ }^{2}$ McGill University Faculty of Medicine, Department of Obstetrics and Gynecology, Montreal, Quebec, Canada \\ ${ }^{3}$ Düzce University Faculty of Medicine, Department of Obstetrics and Gynecology, Düzce, Turkey \\ ${ }^{4}$ Afyon Health Sciences University Hospital, Clinic of Obstetrics and Gynecology, Afyonkarahisar, Turkey \\ 5 Antalya Training and Research Hospital, Clinic of Obstetrics and Gynecology, Antalya, Turkey \\ 6 Originelle Women's Health and Fertility Center, Montreal, Quebec, Canada
}

\begin{abstract}
Objective: To investigate whether letrozole priming could be used efficiently in patients undergoing in vitro maturation (IVM) as compared with folliclestimulating hormone (FSH) priming.

Materials and Methods: This is a retrospective analysis of 63 patients who underwent IVM due to the high risk of Ovarian Hyperstimulation syndrome (OHSS) ( $\mathrm{n}=39)$, cancerophobia $(\mathrm{n}=16)$, and desire for IVM after failed in vitro fertilization attempts $(\mathrm{n}=8)$. Forty-two patients received FSH priming and 21 patients received letrozole priming.

Results: The patients who had FSH or letrozole priming were statistically similar with respect to age, body mass index, duration of infertility, basal antral follicle count, serum anti-Müllerian hormone levels, and IVM indications ( $p>0.05$ for all). When compared with the FSH priming group, the number of germinal vesicle oocytes, metaphase II and fertilized oocytes were significantly higher ( $\mathrm{p}=0.003, \mathrm{p}=0.001$, and $\mathrm{p}=0.016$, respectively), but the number of metaphase I oocytes was significantly lower in the letrozole priming group ( $\mathrm{p}=0.002)$. The patients who received FSH and letrozole priming had statistically similar rates of implantation (33.3\% vs $37.0 \%, \mathrm{p}=0.709)$, clinical pregnancy ( $31.5 \%$ vs $33.3 \%$, p=0.848), twinning ( $1.9 \%$ vs $3.7 \%$, p=0.611), and live birth (24.1\% vs $29.6 \%, \mathrm{p}=0.682)$

Conclusion: Potential indications for IVM include patients with increased risk for OHSS and contraindication for hyperestrogenism. Aromatase inhibitors can be used to preserve the fertility of patients with estrogen-sensitive cancers. Letrozole priming appears to be an efficient approach in patients who undergo IVM, with likely less cost than FSH priming.

Keywords: Cancerphobia, in vitro maturation techniques, letrozole, oocytes, Ovarian Hyperstimulation syndrome, pregnancy

Öz

Amaç: Bu çalışma, in vitro maturasyona (IVM) giren hastalarda letrozol kullanımının etkinliğinin folikül uyarıcı hormon (FSH) ile öncüllenmiş uygulama ile karşılaştırılmasını araştırmayı amaçlamaktadır.

Gereç ve Yöntemler: Bu retrospektif çalışma, yüksek Yumurtalık Hiperstimülasyon sendromu (OHSS) riski (n=39), kanserfobisi (n=16) ve başarısız tüp bebek tedavisi sonrası IVM denemk isteyen (n=16) IVM’ye giren 63 hastanın analizidir. Kurk iki hasta FSH ile öncüllenmiş, 21 hasta ise letrozol ile öncüllenmiştir.

Bulgular: FSH veya letrozol öncüllenmiş olan hastalar yaş, vücut kitle indeksi, infertilite süresi, bazal antral folikül sayısı, serum anti-Müllerian hormon seviyeleri ve IVM endikasyonları açısından istatistiksel olarak benzerdi (tümü için p>0,05). FSH öncüllenmiş grupla karşılaştırıldığında, letrozol öncüllenmiş grupta germinal vezikül oositleri, Metafaz II ve döllenmiş oositlerin sayısı anlamlı olarak daha yüksekti (sırasıyla p=0,003, p=0,001 ve p=0,016); ancak Metafaz I oositlerinin sayısı letrozol öncüllenmiş grubunda anlamlı olarak daha düşüktü $(p=0,002)$. FSH ve letrozol öncüllenmiş hastalarda istatistiksel
\end{abstract}

PRECIS: Letrozole priming in vitro maturation protocol has promising results in cases with cancerphobia and patients with history of OHSS. The outcomes are comparable with FSH priming IVM.

Address for Correspondence/Yazışma Adresi: Şafak Hatırnaz Assoc. Prof.,

Medicana Samsun International Hospital, Samsun, Turkey

Phone: +90 3623110505 E-mail: safakhatirnaz@gmail.com ORCID ID: orcid.org/0000-0001-8859-0639

Received/Geliș Tarihi: 25.06.2020 Accepted/Kabul Tarihi: 04.10.2020

${ }^{\oplus}$ Copyright 2020 by Turkish Society of Obstetrics and Gynecology

Turkish Journal of Obstetrics and Gynecology published by Galenos Publishing House. 
olarak benzer implantasyon oranları (\%33,3'e karşı \%37,0, p=0,709), klinik gebelik (\%31,5'e karşı \%33,3, p=0,848), ikiz gebelik (\%1,9'a karşı \%3,7, p=0,611) ve canlı doğum (\%24,l'e karşı \%29,6, p=0,682) gözlenmiştir.

Sonuç: IVM için potansiyel endikasyonlar; artmış OHSS riski ve hiperinsulinizm için kontrendikasyon olmasıdır. Aromataz inhibitörleri östrojen sensitif kanserlerde fertilite koruma amaçlı kullanılabilmektedir. Letrozol ile öncülleme IVM tedavisine giren hastalarda etkin bir yaklaşım olarak görülmekte ve FSH öncüllenmiş tedaviden olasılıkla daha uygun maliyette olmaktadır.

Anahtar Kelimeler: Kanserfobi, in vitro maturasyon teknikleri, letrozol, oositler, Ovarian Hiperstimulasyon sendromu, gebelik

\section{Introduction}

In vitro maturation (IVM) refers to the retrieval of immature oocytes from antral follicles, with the final stages of meiosis completed during in vitro culture ${ }^{(1)}$. Potential indications for IVM include patients with increased risk for Ovarian Hyperstimulation syndrome (OHSS), patients with limited time for ovarian stimulation, and patients with a contraindication for elevated concentrations of estradiol ${ }^{(1-3)}$.

The primary benefits of IVM are the reduction in gonadotropin exposure, the subsequent decrease in the risk of OHSS, and facilitation of oocyte retrieval in oncology patients who need to undergo gonadotoxic treatment without adequate time for ovarian stimulation ${ }^{(3,4)}$. Another benefit of IVM is the avoidance from ovarian stimulation-related hyperestrogenism in oncology patients with hormone-sensitive tumors ${ }^{(4,5)}$.

Letrozole is an aromatase inhibitor that blocks the conversion of androgens into estrogens in the ovarian milieu ${ }^{(6)}$. Letrozole exerts its primary action by increasing endogenous secretion of follicle-stimulating hormone (FSH) and a secondary action by giving rise to a hyperandrogenic microenvironment, which triggers the development of primordial follicles ${ }^{(7)}$. Therefore, it has been hypothesized that letrozole could be used to achieve ovarian stimulation in women with hormone-sensitive tumors without exposing them to sustained elevated estrogen levels ${ }^{(8)}$. The avoidance from hyperestrogenism might also help to relieve the anxiety of infertile women who might be concerned about the long-term probability of developing estrogensensitive cancers while they are undergoing an assisted reproductive cycle ${ }^{(8-10)}$. On the other hand, the emergence of a hyperandrogenic microenvironment might be beneficial in cases of oocyte maturation arrest ${ }^{(11,12)}$.

This study aimed to investigate whether letrozole priming could be used efficiently for patients who were to undergo IVM treatment due to a high risk of OHSS, desire for IVM or fear for estrogen-sensitive cancers.

\section{Materials and Methods}

This is a retrospective analysis of 63 patients who underwent IVM treatment due to the high risk of OHSS ( $n=39$ ), fear for estrogen-sensitive cancers $(n=16)$, and desire IVM after IVF failure ( $\mathrm{n}=8$ ) at Samsun Medicana International Hospital between September 2017 and January 2020. The primary risk factors for OHSS included young age ( $<33$ years), polycystic ovaries on transvaginal ultrasonography ( $>24$ antral follicles), and previous OHSS ${ }^{(13)}$. The women with cancerophobia were those with Polycystic Ovary syndrome (PCOS) who had fibrocystic breast disease $(\mathrm{n}=10)$, a family history of breast cancer $(\mathrm{n}=3)$, and family history of endometrium cancer $(n=3)$. This study was approved by the Institutional Review Board of the study center (approval no: 3/2020) and conducted in accordance with the ethical principles outlined in the Declaration of Helsinki. All participants gave written informed consent.

Forty-two patients received FSH- human chorionic gonadotropin (hCG) priming and 21 patients received letrozole-hCG priming. Cancerophobia in the letrozole priming group was related to fibrocystic breast disease $(n=5)$, positive family history of breast cancer $(n=1)$ or endometrial cancer $(n=1)$. Patients with hyperprolactinemia, Cushing's syndrome, non-classic congenital adrenal hyperplasia, adrenal and ovarian androgen-secreting tumors were excluded. Women whose partners had azoospermia, cryptozoospermia, and severe oligoasthenoteratozoospermia were also excluded.

\section{Gonadotropin and Letrozole Priming}

The standard protocol for IVM indicated FSH-hCG priming at the study center, as previously described ${ }^{(14)}$. IVM with letrozole priming was used only for the aforementioned indications. Beginning on the $3^{\text {rd }}$ day of a spontaneous or an induced menstrual cycle, 21 patients had a daily dose of $5 \mathrm{mg}$ letrozole (Femara ${ }^{\circledR}$, Novartis, Basel, Switzerland) for 3 days, and 42 patients received recombinant FSH (Gonal- ${ }^{\circledast}$, Merck-Serono, Geneva, Switzerland) at a daily dosage of 75 IU for 3 days. Either 10,000 IU of urinary hCG (Pregnyl ${ }^{\circledR}$, Organon, Amsterdam, Netherlands) or $250 \mu \mathrm{g}$ recombinant hCG (Ovitrelle ${ }^{\circledR}$, Serono, Geneva, Switzerland) was administered when the leading follicle size was 10 to $12 \mathrm{~mm}$ and endometrial thickness was at least $8 \mathrm{~mm}$ on transvaginal ultrasonography in the mid-sagittal plane. Under the guidance of transvaginal ultrasonography, oocyte pickup was performed using a 17-gauge double-lumen aspiration needle with an aspiration pressure of $80 \mathrm{mmHg} 36$ 38 hours after hCG administration.

\section{In Vitro Maturation}

Follicular aspirates were collected into $14 \mathrm{~mL}$ Falcon tubes (Falcon, Code 352001), which were kept at $37^{\circ} \mathrm{C}$ and filtered using a strainer (Falcon-70 $\mu \mathrm{m}$ pore size-, Code 352350 ). Under a stereomicroscope (Olympus SZ 61, Shibuya, Tokyo, Japan), oocytes were isolated into the perimeter of a Falcon centerwell dish containing flushing medium without heparin and subsequently incubated for two to three hours in IVM media. Upon completion of oocyte collection, the final medium was prepared using commercially available IVM medium (Vial 2 Medi-Cult IVM System), $0.5 \mathrm{~mL}$ of patient serum, $50 \mu \mathrm{L}$ FSH prepared from a stock solution of $0.075 \mathrm{IU} / \mathrm{mL}$ (75 IU GONAL-f was diluted with $10 \mathrm{~mL}$ IVM medium and $5 \mu \mathrm{L}$ hCG, 
and then incubated at $37{ }^{\circ} \mathrm{C}$ and $6 \% \mathrm{CO}_{2}$ and $5 \% \mathrm{O}_{2}$. After incubation in LAG medium, oocytes were placed equally in the wells of a four-well dish (Nunc, Roskilde, Denmark) containing $0.6 \mathrm{~mL}$ of final IVM medium covered with liquid paraffin and incubated for 26-28 hours. Nuclear maturity of oocytes was not assessed any further.

\section{Intracytoplasmic Sperm Injection}

Intracytoplasmic sperm injection (ICSI) was performed in all IVM cycles. The spermatozoa were prepared using a three-layer PureSperm gradient (Codes PSB 100 and PS100-100, Mölndal, Gothenburg, Sweden). Removal of the cumulus and corona cells was performed in a hyaluronidase-containing medium using Pasteur pipettes after a 26-28 h incubation period. The oocytes were then transferred to U-IVF medium for culture. All ICSI procedures were performed in Falcon Petri dish with droplets of PVP containing medium for sperms (Vitrolife, Code $10111,5 \times 0.1 \mathrm{~mL}$ ) and droplets of flushing medium without heparin for oocytes.

When the ICSI procedure was completed, the oocytes were placed into ISM 1 medium for culture. After the oocyte fertilization was evaluated in droplets of ISM 1 medium, incubation of fertilized oocytes was continued for 24-hours (which made up 48-hours in total). The first fertilization check, which occurred 16-18 $\mathrm{h}$ after ICSI was determined by the presence of two distinct pronuclei and two polar bodies within the oocytes in ISM 1 medium through an inverted microscope at x200 magnification. This was repeated 24 hours later.

The classification system introduced by Veeck was used for the evaluation of embryo grade on the third day of culture. The embryos were graded as follows: Grade 1 - embryo with blastomeres of equal size, no cytoplasmic fragments; Grade 2 - embryo with blastomeres of equal size, minor cytoplasmic fragments or blebs: Grade 3 - embryo with blastomeres of distinctly unequal size, none or few cytoplasmic fragments ${ }^{(15)}$.

Embryo transfer was performed using a Wallace embryo transfer catheter (Wallace, UK) under abdominal ultrasonography guidance and placed 1.5 to $2.5 \mathrm{~cm}$ from the fundus. Women aged younger than 35 years could only have a single embryo transferred, and a maximum of two embryos could be transferred to women aged over 35 years. Taking endometrial thickness into consideration, fresh embryo transfers were performed on day 3 or day 5. To prepare the endometrium for embryo transfer, an oral estrogen tablet was administered at a daily dosage of 4 mg (Estrofem ${ }^{\circledR}$, Novo Nordisk, Bagsværd, Denmark) beginning from the third day of menstrual cycle. Luteal phase support was begun the day following OPU, which was provided with a vaginal progesterone capsule at a daily dosage of $200 \mathrm{mg}$ (Progestan ${ }^{\circledast}$, Koçak Farma, İstanbul, Turkey). Estrogen tablets and progesterone capsules were continued until the first fetal heartbeat was detected.

Clinical pregnancy was defined as the presence of at least one gestational sac in the uterus. No IVM cycles were cancelled in this study.

\section{Statistical Analysis}

Collected data were analyzed using the Statistical Package for the Social Sciences version 22.0 software (SPSS IBM Inc., Armonk, NY, USA). Continuous variables are expressed as mean \pm standard deviation and categorical variables are denoted as numbers or percentages. Continuous variables were compared using Student's t-test or the Mann-Whitney $\mathrm{U}$ test, whereas categorical variables were compared using the chi-square test. Two-tailed $\mathrm{p}$ values $\leq 0.05$ were regarded as statistically significant. A post-hoc analysis was performed to determine that a cohort size of 63 women (undergoing IVM for minimizing OHSS risk and preventing oocytes maturation arrest) had $67.6 \%$ power to detect a difference at the 0.05 significance level.

\section{Results}

Table 1 compares the baseline characteristics of the 21 patients who had letrozole priming and 42 patients who received FSH priming for IVM treatment. There were no significant group differences in age, body mass index, duration of infertility, basal antral follicle count, and serum AMH concentrations ( $p>0.05$ for all). The patients who underwent FSH and letrozole priming were also statistically similar in the aspect of IVM indications (Table 2). Table 3 summarizes the laboratory findings of the patients.

Table 1. Baseline characteristics of the patients

\begin{tabular}{l|l|l|l|} 
& $\begin{array}{l}\text { FSH } \\
\text { priming }\end{array}$ & $\begin{array}{l}\text { Letrozole } \\
\text { priming }\end{array}$ & p \\
\hline Age (years) & $29.2 \pm 4.8$ & $31.1 \pm 4.2$ & 0.129 \\
\hline Body mass index $\left(\mathrm{kg} / \mathrm{m}^{2}\right)$ & $27.27 \pm 6.02$ & $25.16 \pm 4.35$ & 0.159 \\
\hline $\begin{array}{l}\text { Duration of infertility (years) } \\
\text { Antral follicle count (n) }\end{array}$ & $6 \pm 3.19$ & $6.1 \pm 3.4$ & 0.87 \\
\hline $\begin{array}{l}\text { Anti-Müllerian hormone (ng/ } \\
\text { mL) }\end{array}$ & $5.56 \pm 1.35$ & $6.04 \pm 1.36$ & 0.191 \\
\hline $\begin{array}{l}\text { Values are given as mean } \pm \text { SD; FSH: Follicle-stimulating hormone, SD: Standard } \\
\text { deviation }\end{array}$ & & & \\
\hline
\end{tabular}

Table 2. Indications for in vitro maturation

\begin{tabular}{|l|l|l|l|}
\hline & $\begin{array}{l}\text { FSH } \\
\text { priming }\end{array}$ & $\begin{array}{l}\text { Letrozole } \\
\text { priming }\end{array}$ & $\mathrm{p}$ \\
\hline $\begin{array}{l}\text { Oocyte maturation arrest } \\
\begin{array}{l}\text { PCOS patients with } \\
\text { cancerophobia }\end{array}\end{array}$ & $9(9.5)$ & $4(19)$ & 0.285 \\
\hline Increased risk for OHSS & $29(69.1)$ & $10(47.7)$ & 0.099 \\
\hline Young age (<33 years) & $3(7.1)$ & - & 0.209 \\
\hline Polycystic ovaries on TV-USG & $15(35.7)$ & $5(23.8)$ & 0.338 \\
\hline Previous OHSS & $11(26.2)$ & $5(23.8)$ & 0.838
\end{tabular}

Values are given as number (percentage); FSH: Follicle-stimulating hormone, PCOS: Polycystic Ovary syndrome, OHSS: Ovarian Hyperstimulation syndrome; TV-USG: Transvaginal ultrasonography 
Both the FSH and letrozole priming groups were statistically similar concerning the endometrium thickness on the hCG day, time to oocyte pick up, retrieved oocytes counts, and single or double embryo transfers ( $>0.05$ for all). When compared with the FSH priming group, a significantly higher number of germinal vesicle oocytes, metaphase II, and fertilized oocytes $(\mathrm{p}=0.003, \mathrm{p}=0.001, \mathrm{p}=0.016$, respectively) and a significantly lower number of metaphase I oocytes and grade 3 embyros were detected in the letrozole priming group $(\mathrm{p}=0.002$, $\mathrm{p}=0.007$, respectively). The number of three-cell embryos was also significantly lower in the letrozole priming group when compared with the FSH priming group ( $\mathrm{p}=0.007$ ).

Table 4 shows the pregnancy outcomes of the patients. The patients who received FSH and letrozole priming had statistically similar rates of implantation ( $33.3 \%$ vs $37 \%, \mathrm{p}=0.709$ ), clinical pregnancy $(31.5 \%$ vs $33.3 \%, \mathrm{p}=0.848)$, twin pregnancy $(1.9 \%$ vs $3.7 \%, \mathrm{p}=0.611$ ), and live birth ( $24.1 \%$ vs $29.6 \%, \mathrm{p}=0.682$ ).

\section{Discussion}

By definition, IVM refers to the maturation of collected immature oocytes under the influence of hormones that exist within the

Table 3. Laboratory findings of the patients

\begin{tabular}{l|llll|}
\hline & $\begin{array}{l}\text { FSH } \\
\text { priming }\end{array}$ & $\begin{array}{l}\text { Letrozole } \\
\text { priming }\end{array}$ & p \\
\hline $\begin{array}{l}\text { Endometrial thickness at hCG } \\
\text { day (mm) }\end{array}$ & $9.07 \pm 1.25$ & $9.63 \pm 1.68$ & 0.138 \\
\hline Time to oocytes pick up (days) & $13.2 \pm 1.8$ & $14.0 \pm 1.8$ & 0.123 \\
\hline Retrieved oocytes (n) & $12.8 \pm 6.8$ & $14.6 \pm 3.6$ & 0.273 \\
\hline Germinal vesicle oocytes (n) & $3.4 \pm 1.0$ & $8.1 \pm 6.5$ & $0.003^{*}$ \\
\hline Metaphase I oocytes (n) & $3.8 \pm 1.5$ & $2.6 \pm 0.7$ & $0.002^{*}$ \\
\hline Metaphase II oocytes (n) & $6.3 \pm 3.1$ & $9.4 \pm 2.7$ & $0.001^{*}$ \\
\hline Fertilized oocytes (n) & $5.5 \pm 2.8$ & $6.8 \pm 1.5$ & $0.016^{*}$ \\
\hline Embryo transfer (n, \%) & & & 0.621 \\
\hline Single embryo & $30(71.4)$ & $15(71.4)$ & - \\
\hline Double embryo & $12(28.6)$ & $6(28.6)$ & - \\
\hline Embryo grade (n, \%) & & & $0.007^{*}$ \\
\hline Grade 1 & $5(2.4)$ & $7(23.8)$ & - \\
\hline Grade 2 & $28(57.1)$ & $15(61.9)$ & - \\
\hline Grade 3 & $21(40.5)$ & $5(14.3)$ & - \\
\hline Embryo quality (n, \%) & & & $0.007^{*}$ \\
\hline One-cell embryo & $5(4.8)$ & $5(18.5)$ & - \\
\hline Two-cell embryos & $4(2.4)$ & $7(26)$ & - \\
\hline Three-cell embryos & $31(66.7)$ & $10(37)$ & - \\
\hline $\begin{array}{l}\text { Four-cell embryos } \\
\text { stimulating hormone, hCG: Human chorionic gonadotropin, *significant difference, SD: }\end{array}$ & & \\
\hline Standard deviation & & & - \\
\hline
\end{tabular}

Table 4. Comparison of pregnancy outcomes of two groups

\begin{tabular}{|c|c|c|c|}
\hline & $\begin{array}{l}\text { FSH } \\
\text { priming }\end{array}$ & $\begin{array}{l}\text { Letrozole } \\
\text { priming }\end{array}$ & $\mathrm{p}$ \\
\hline Implantation rate per transfer & $18 / 54(33.3)$ & $10 / 27(37)$ & 0.709 \\
\hline $\begin{array}{l}\text { Clinical pregnancy rate per } \\
\text { transfer }\end{array}$ & $17 / 54(31.5)$ & 9/27 (33.3) & 0.848 \\
\hline $\begin{array}{l}\text { Singleton pregnancy rate per } \\
\text { transfer }\end{array}$ & $16 / 54(29.6)$ & $7 / 27(25.9)$ & 0.688 \\
\hline $\begin{array}{l}\text { Twin pregnancy rate per } \\
\text { transfer }\end{array}$ & $1 / 54(1.9)$ & $1 / 27(3.7)$ & 0.611 \\
\hline Live birth rate per transfer & $13 / 54(24.1)$ & $8 / 27(29.6)$ & 0.682 \\
\hline
\end{tabular}

culture media. Thus, hormones are not administered to patients undergoing IVF treatment ${ }^{(16,17)}$. However, the general opinion about IVM is that a short priming protocol with FSH stimulation increases the chance for oocyte maturation and implantation in patients with PCOS. This short priming protocol involves the administration of FSH at a dose of 75 IU to $150 \mathrm{IU}$ for a period of two to five days. FSH stimulation at the beginning of a cycle increases the number of immature oocytes retrieved and thus clinical pregnancy rates in IVM cycles ${ }^{(18-20)}$. Accordingly, this study adopted an IVM protocol indicating the administration of recombinant FSH at a dose of $75 \mathrm{IU}$ for three days.

In this study, 16 patients with PCOS refused to receive FSH priming because they had cancerophobia due to fibrocystic breast disease and a positive family history for breast and endometrium cancer. Therefore, priming was performed using an aromatase inhibitor, namely letrozole, in seven patients with PCOS.

In this study, the primary indications for IVM treatment were the avoidance from OHSS and previously failed IVF desiring IVM. It is well known that IVM is the only assisted reproduction technique that has been proved to be devoid of OHSS risk. Recent meta-analyses reported that patients treated with IVM had significantly higher implantation and clinical pregnancy rates, as well as significantly lower miscarriage and cycle cancellation rates ${ }^{(22,23)}$. The maturation of human oocytes is naturally arrested at the germinal vesicle stage when the oocytes need gonadotropin stimulation and the metaphase II stage when oocytes are waiting for fertilization. A therapeutic approach for failed IVF could be the IVM of immature oocytes within culture media enriched with factors necessary for oocyte maturation $^{(11,12)}$, if compromised in vivo.

Due to the wide variations in priming protocols, varying numbers between $8 \%$ and $40 \%$ have been specified as the clinical pregnancy rates and live birth rates in IVM cycles ${ }^{(24)}$. Similarly, our previous study reported clinical pregnancy rates of $44.6 \%$ and $44.7 \%$ and live birth rates of $34.9 \%$ and $34.2 \%$ for single-embryo transfer and double-embryo transfers in IVM cycles with FSH priming ${ }^{(14)}$. As for the present study, the clinical pregnancy and live birth rates were respectively $31.5 \%$ 
and $24.1 \%$ in IVM cycles with gonadotropin priming. Although clinical pregnancy and live birth rates tended to be higher in IVM cycles with letrozole priming (33.3\% and 29.6\%), there were no statistically significant differences.

A new indication for IVM has been defined as a convenient therapeutic approach for infertile patients who have been diagnosed as having malignancies and scheduled for oncofertility treatment. The basic rationale for this definition is the feasibility of IVM for preserving oocytes and embryos and thus, future fertility, whenever conventional in vitro fertilization is not an option. A potential factor that might delay the oncology treatment can also be avoided because IVM prevents the risk of OHSS. Additionally, this technique can be used to replace an IVF cycle that would otherwise end up with excessive follicular growth and subsequent cycle cancellation ${ }^{(25,26)}$.

Another advantage of IVM treatment is that it can be started immediately at any time of the menstrual cycle without stimulating ovaries. Therefore, IVM emerges as an appropriate technique for preserving the fertility of oncology patients in whom the initiation of chemotherapy, radiotherapy or surgical treatment cannot be delayed ${ }^{(1,2)}$. Another advantage of this assisted reproduction technique is that serum estrogen concentrations remain low throughout an IVM cycle. Therefore, IVM has been established as a safe and effective method for fertility preservation in patients with estrogen-sensitive tumors ${ }^{(25,26)}$.

It is also well known that aromatase inhibitors can be used as single agents or adjuncts to FSH-containing ovulation induction regimens for preserving the fertility of patients with estrogen-sensitive breast cancer. Aromatase inhibitors would reduce supra-physiologically serum concentrations of estradiol, suppress local production of estrogen within the tumor tissue, and induce follicular growth in women with estrogen-sensitive malignancies. Combining gonadotropins with aromatase inhibitors would augment the ovarian stimulation without a profound increase in serum estradiol levels ${ }^{(27,28)}$.

\section{Conclusion}

The findings of this study suggest that IVM treatment with letrozole priming might be an efficient approach for patients who have a high risk for OHSS or fear for estrogen-sensitive tumors. However, these findings should be interpreted carefully as their power is limited by its retrospective design, small cohort size, technical inadequacy for cryopreservation, and lack of longterm data. Further research is warranted to clarify the clinical implications of letrozole priming in IVM cycles. A prospective study of letrozole-primed IVM should be considered.

\section{Ethics}

Ethics Committee Approval: This study was approved by the Institutional Review Board of the study center (approval no: 3/2020).
Informed Consent: All participants gave written informed consent.

Peer-review: Externally and internally peer-reviewed.

\section{Authorship Contributions}

Surgical and Medical Practices: S..H., E.S.H., Concept: Ş.H., M.D., S.T., M.K.P., Design: \$.H., A.B., O.E., M.D., E.S.H., Data Collection or Processing: S..H., A.B., M.K.P., M.D., O.E., Analysis or Interpretation: M.K.P., A.B., O.E., M.D., S.T., S.H., Literature Search: E.S.H., M.D., S..H., Writing: S..H., E.S.H., M.K.P.

Conflict of Interest: The authors report no conflict of interest. Financial Disclosure: Authors have no financial interests about the research.

\section{References}

1. Walls ML, Hart RJ. In vitro maturation. Best Pract Res Clin Obstet Gynaecol 2018;53:60-72.

2. Sauerbrun-Cutler MT, Vega M, Keltz M, McGovern PG. In vitro maturation and its role in clinical assisted reproductive technology. Obstet Gynecol Surv 2015;70:45-57.

3. Khalili MA, Shahedi A, Ashourzadeh S, Nottola SA, Macchiarelli G, Palmerini MG. Vitrification of human immature oocytes before and after in vitro maturation: a review. J Assist Reprod Genet 2017;34:1413-26.

4. Sonigo C, Grynberg M. In vitro oocyte maturation for female fertility preservation. Gynecol Obstet Fertil 2014;42:657-60.

5. Grynberg M, El Hachem H, de Bantel A, Benard J, le Parco S, Fanchin R. In vitro maturation of oocytes: uncommon indications. Fertil Steril 2013;99:1182-8.

6. Nguyen TT, Doan HT, Quan LH, Lam NM. Effect of letrozole for ovulation induction combined with intrauterine insemination on women with polycystic ovary syndrome. Gynecol Endocrinol 2020;36:860-3

7. Tanbo T, Mellembakken J, Bjercke S, Ring E, Åbyholm T, Fedorcsak P. Ovulation induction in polycystic ovary syndrome. Acta Obstet Gynecol Scand 2018;97:1162-7.

8. Pereira N, Kligman I, Hunt R, Kopparam R, Wahmann B, Rosenwaks Z. Fertility preservation with random-start controlled ovarian stimulation and embryo cryopreservation for early pregnancyassociated breast cancer. Gynecol Endocrinol 2019;35:214-6.

9. Sonigo C, Sermondade N, Calvo J, Benard J, Sifer C, Grynberg M. Impact of letrozole supplementation during ovarian stimulation for fertility preservation in breast cancer patients. Eur J Obstet Gynecol Reprod Biol X 2019;4:100049.

10. Zhang Z, Huang H, Feng F, Wang J, Cheng N. A pilot study of gonadotropin-releasing hormone agonist combined with aromatase inhibitor as fertility-sparing treatment in obese patients with endometrial cancer. J Gynecol Oncol 2019;30:e61.

11. Sánchez F, Lolicato F, Romero S, De Vos M, Van Ranst H, Verheyen $G$, et al. An improved IVM method for cumulus-oocyte complexes from small follicles in polycystic ovary syndrome patients enhances oocyte competence and embryo yield. Hum Reprod 2017;32:205668.

12. Santiquet NW, Greene AF, Becker J, Barfield JP, Schoolcraft WB, Krisher RL. A pre-in vitro maturation medium containing cumulus oocyte complex ligand-receptor signaling molecules maintains meiotic arrest, supports the cumulus oocyte complex and improves 
oocyte developmental competence. Mol Hum Reprod 2017;23:594606.

13. Fiedler K, Ezcurra D. Predicting and preventing ovarian hyperstimulation syndrome (OHSS): the need for individualized not standardized treatment. Reprod Biol Endocrinol 2012;10:32.

14. Hatirnaz S, Hatirnaz E, Dahan MH, Tan SL, Ozer A, Kanat-Pektas $\mathrm{M}$, et al. Is elective single-embryo transfer a viable treatment policy in in vitro maturation cycles? FertilSteril 2016;160:1691-5.

15. Hossain A, Phelps J, Agarwal A, Sanz E, Mahadevan M. A Review of The Society for Assisted Reproductive Technology Embryo Grading System and Proposed Modification. Int J Fertil Steril 2016;10:1417.

16. Dahan MH, Tan SL, Chung J, Son WY. Clinical definition paper on in vitro maturation of human oocytes. Hum Reprod 2016;31:13836.

17. De Vos M, Smitz J, Thompson JG, Gilchrist RB. The definition of IVM is clear-variations need defining. Hum Reprod 2016;31:24115.

18. Junk SM, Yeap D. Improved implantation and ongoing pregnancy rates after single-embryo transfer with an optimized protocol for in vitro oocyte maturation in women with polycystic ovaries and polycystic ovary syndrome. Fertil Steril 2012;98:888-92.

19. Walls ML, Hunter T, Ryan JP, Keelan JA, Nathan E, Hart RJ. In vitro maturation as an alternative to standard in vitro fertilization for patients diagnosed with polycystic ovaries: a comparative analysis of fresh, frozen and cumulative cycle outcomes. Hum Reprod 2015;30:88-96.

20. De Vos M, Ortega-Hrepich C, Albuz FK, Guzman L, Polyzos NP, Smitz J, et al. Clinical outcome of none hCG-primed oocyte in vitro maturation treatment in patients with polycystic ovaries and polycystic ovary syndrome. Fertil Steril 2011;96:860-4.
21. Lindenberg S. New approach in patients with polycystic ovaries, lessons for everyone. Fertil Steril 2013;99:1170-2.

22. Siristatidis C, Sergentanis TN, Vogiatzi P, Kanavidis P, Chrelias C, Papantoniou N, et al. In vitro maturation in women with vs. without polycystic ovarian syndrome: a systematic review and meta-analysis. PLoS One 2015;10:e0134696.

23. De Geyter C, Calhaz-Jorge C, Kupka MS, Wyns C, Mocanu E, Motrenko T, et al. ART in Europe, 2014: results generated from European registries by ESHRE: The European IVF-monitoring Consortium (EIM) for the European Society of Human Reproduction and Embryology (ESHRE). Hum Reprod 2018;33:1586-601.

24. Shirasawa H, Terada Y. In vitro maturation of human immature oocytes for fertility preservation and research material. Reprod Med Biol 2017;16:258-67.

25. Shoham G, Levy-Toledano R, Leong M, Weissman A, Yaron Y, Shoham Z. Oncofertility: insights from IVF specialists-a worldwide web-based survey analysis. J Assist Reprod Genet 2019;36:1013-21.

26. Fatum M, McVeigh E, Child T. The case for aromatase inhibitors use in oncofertility patients. Should aromatase inhibitors be combined with gonadotropin treatment in breast cancer patients undergoing ovarian stimulation for fertility preservation prior to chemotherapy? A debate. Hum Fertil (Camb) 2013;16:235-40.

27. Comtet M, Sonigo C, Valdelièvre C, Sermondade N, Sifer C, Grynberg M. Fertility preservation in breast cancer patients: the state of art in 2014? Bull Cancer 2015;102:443-53.

28. Takai Y. Recent advances in oncofertility care worldwide and in Japan. Reprod Med Biol 2018;17:356-68. 